\title{
イネわい化病に対する早期栽培イネ品種の耐病性
}

\author{
平 尾 重 太 郎 (農林水産省九州農業試験場)
}

\section{Evaluation of rice varieties in early-season culture for resistance to rice waika disease}

\author{
Jutaro HiRAo \\ (Kyushu National Agricultural Experiment Station, Chikugo, Fukuoka 833)
}

\begin{abstract}
Nephotettix cincticeps adults were confined to infected source rice plants by cages for a $24-\mathrm{h}$ acquisition access period at $25^{\circ} \mathrm{C}$. Immediately after the acquisition, the insects were placed one couple per rice seedling at the 2-leaf stage in a test tube for a $24-\mathrm{h}$ inoculation access period at $25^{\circ} \mathrm{C}$. The inoculated seedlings were grown in pots for disease development. Based on the percentage of diseased plants, 3 of 13 varieties tested with 3 replicates were determined to be moderately resistant and others were susceptible to the virus. No resistant varieties were detected. The height of diseased plants was reduced in all of the varieties.
\end{abstract}

イネわい化病に耐病性の品種間差異があることは，本 病の原因がまだ不明で，いわゆる「わい性症状」と呼称 されていたときにも，既に観察されていた。そして，症 状の発生原因が虫媒のウイルス病であることが判明した のちは，耐病性の品種間差異（普通期品種）は接種試験 によっても確認され122), 現在一部の研究機関では, 普 通期を対象に耐病性品種の育成が武みられている。

南九州とくに鹿児島県では，1974・'75 两年に本病は 普通期刬培で多発したにもかかわらず, 早期裁培での発 生は全く認められなかった。このことは宮崎罧でも同様 であり，早期栽培で発生しなかった理由は不明のままで ある。前述のように, 普通期栽培では高度な耐病性品種 が見出されているが，早期栽培品種の耐病性は全く不明 である。このような事情から，幼苗期接種により早期载 培品種の耐病性を検定したので，その結果を報告する。

本文に先だち，供試イネ品種の種子をいただいた宮崎

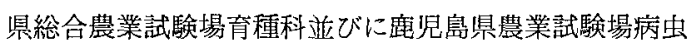
部の各位に，嬮くお礼を申しあげる。

\section{材料および方法}

試験は1977年に行い，第 1 表の上うに時期をかえて 3 回反覆した。ウイルスの接種はッマグロヨコバイの成虫 を用いた。第 1,2 回目試験の供試虫は虫害第 3 研究室 で累代飼育中 $\left(25^{\circ} \mathrm{C}\right)$ の羽化 5 日以内のもので, 第 3 回 目は野外で採集した第 2 回成虫であった。

ウイルスの獲得吸汁のため, リ病イネ(品種：レイホ ウ）にサラン網製円筒をかぶせ，成虫を集団で24時間 $\left(25^{\circ} \mathrm{C}\right)$ 放飼した。獲得吸汁後直ちに成虫を試験管内の 各供武イネ品種苗（2葉期）1本に，雌雄 1 対を 24 時間 $\left(25^{\circ} \mathrm{C}\right)$ 接種吸汁させた。接種苗はポット(1/5,000a)
当り 3 株, 比較のため無接種苗 1 株を，それぞれ 1 本植 えとして移植した。

供試品種は南九州の早期栽培に用いられている主要 13 品種で，比較に感受性で普通期品種のレイホウを用い た。各回 1 品種当りの供試苗数は30本前後であった。発 病調查は1 ネ生育期間中随特行った。生育調查は株の最 長茎の草丈，程長および茎数（穂数）について，移植後 から数回行った。

\begin{tabular}{|c|c|c|c|}
\hline \multicolumn{2}{|c|}{ 第 1 表 } & 験 & 件 \\
\hline $\begin{array}{l}\text { 試験 } \\
\text { 回次 }\end{array}$ & 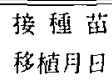 & 出 穂 期 & 生青場所 \\
\hline 1 & $3.30-4.3$ & 6 月第 $4-5$ 半旬 & 寒冷紗張りハウス \\
\hline 2 & $5.14-16$ & 7 月第 $5-6$ 半旬 & 野 \\
\hline 3 & $6.12-15$ & 8 月第 $2-3$ 半旬 & 野 \\
\hline
\end{tabular}

\section{結果および考察}

酎病性の検定結果は第 2 表のとおりである。発病株率 は試験回次によってかなり変動した品種もあったがこ二 の変動状態をも考虑して，3回の平均発病株率が20\%以 下を酎病性，20〜40\%を中，41，\%以上を感受性と判定し 耐病性を 3 段階に大別した。その結果，13品種中に耐病 性の品種はなく, 中は宮崎 7 号, タッるモチ, テンリョ ウの 3 品種, 他の 10 品種は感受性であった。とくに山路 早生, ナッコガネ,トドロキワセ, ムッニシキ, ホウネ ンワセはレイホウ並みの感受性であった。なお，鹿児島 県で本病が多発した1974年，同県の早期栽培面積は9, 300 haで，その約70\%に越路早生が作付されていた。

発病株の生育状態は健全株に比べて草丈，程長とも短 縮し，また表示していないが茎数や穂数も娍少した。草 
丈の短縮率が大きい品種では稈長の短縮率も大きかっ た。しかし，生育に対する影響の程度と耐病性との間に は，とくに一定の傾向はみられず，生育への影響は品種 特有なもののようである。

以上の試験結果から，早期裁培で本病の発生がみられ なかったのは，品種の耐病性ではなく，他の要因である ことがおかった。

本病の周年環，とくに冬期加早春に加けてのウイル スの所在は，いままで関係者の努力にもかかわらず見出 されていない。本病がいままでに早期栽培で発生してい ない理由については，本病の周年環が判明したのちに検 討できるであろう。反対に，本病の周年環を究明するに は，早期栽培で発生していないという事実を考虑して， 今後研究をすす女る必要もある。

摘

要

南九州の早期栽培用イネ13品種を供試し，幼苗期接種 によってイネわい化病に対する酎病性を検定した。学の 結果, 耐病性品種はなく, 中程度の耐病性品種は宮崎 7 号, タッえモチ，テンリョウで，他は感受性であった。 発病株は耐病性程度に関係なく, どの品種でも草丈, 稈 長が短縮した。
第2 表是期亿六品種のイネわい化病酎病性

\begin{tabular}{|c|c|c|c|c|c|c|c|}
\hline \multirow[t]{2}{*}{ 品＼cjkstart種 } & \multicolumn{4}{|c|}{ 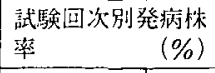 } & \multirow{2}{*}{$\begin{array}{l}\text { 耐病性 } \\
\text { 判 定 }\end{array}$} & \multicolumn{2}{|c|}{ 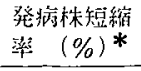 } \\
\hline & 1 & 2 & 3 & 平均 & & 草丈 & 程接 \\
\hline 窝 崎 7 㝑 & - & 30 & 17 & 24 & $\mathrm{M}$ & 8 & 11 \\
\hline$\not ッ \Sigma モ 千$ & 16 & 48 & 23 & 29 & M & 12 & 18 \\
\hline テンリヨウ & 38 & 47 & 29 & 38 & M & 9 & 9 \\
\hline 越 路 卓生 & 40 & 37 & 58 & 45 & S & 6 & 11 \\
\hline 西涬糯 50 号 & 37 & 43 & 61 & 47 & S & 8 & 12 \\
\hline コシヒカリ & 33 & 59 & 48 & 47 & $S$ & 18 & $\ldots * *$ \\
\hline ぜんこうじもち & 40 & 47 & 57 & 48 & $S$ & 10 & 10 \\
\hline ハマミノリ & 48 & 60 & 53 & 54 & $S$ & 13 & 4 \\
\hline 山路 邼生 & 57 & 73 & 72 & 67 & $\mathrm{~S}$ & 14 & 14 \\
\hline ナツコガネ & 59 & 86 & 69 & 71 & S & 9 & 6 \\
\hline トドロキワ七 & 67 & 73 & 76 & 72 & $\mathrm{~S}$ & 16 & 20 \\
\hline 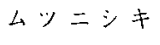 & - & 76 & 71 & 74 & S & 5 & 9 \\
\hline ホウネンワ七 & - & 80 & 78 & 79 & $\mathrm{~S}$ & 14 & 12 \\
\hline レイホウ(比) & 70 & 73 & 80 & 74 & $\mathrm{~S}$ & 10 & 10 \\
\hline
\end{tabular}

注) *: 第 2 回目試騃(出穂揃期調查)

**: 未出穂時調查。

引用 文 献

1) 平尾重太郎 - 井上斉(1976) 九病虫研会報22：104106. 2) 木村俊彦(1976) 九病虫研会報22 : 26-28.

\section{Tungro 判別品種のイネわい化病に対する反応}

岩崎真人・前島 勇* ・ 新海 昭 (農林水産省九州農業試験場 $・ *$ 現農林水産省農薬検査所)

東南アジアに分布する tungro 病は，多くの点でイネ わい化病と類似している。また，インドおよびフィリピ ンでは tungroにいくつかの系統が報告されている3,5)。 本稿では，これらの類縁関係を明らかにする上での参若 とするために, tungro の判別品種》を用いてわい化病 に対する反応を調べた。

判別品種の種子の分竓およびほ場検定の稻菄採取には 当場作物第 1 部作物第 1 研究空に協力していただいた。

\section{試験方法ならびに結果}

実験 I ツマグロヨコバイを用いた試験

接種源として供試したわい化病株は, 1973年筑後市内 で採取し，その後ツマグロヨコバイにて継代したものを 用いた。1976年 5 〜月に, ッマグロヨコバイ雄成虫を 病株に 1 日間接種吸汁させたのち, 直ちに稻苗を 1 本入 れた試験管に 5 頍ずつ 1 日間放飼し，接種を行った。稻 苗は，不完全葉を第 1 葉と数えて $3 \sim 4$ 葉期のものを用 いた。接種苗 2 株と無毒ツマグロヨコバイ吸汁苗（対照
株） 1 株を1/5,000aワグネルポットに同時に移植した。 以後網室にて管理し，11月まで病徽の観察を行った。戻 し接種は，接種約 3 力月後に無毒ッマグロヨコパイ雄成 虫用い，切葉法にて行った。すなわち，接種株 1 秼に 6 頭の無毒虫を用い，獲得财汁・接程吸汁を各 1 日間で,

2 株のレイホウに接種を行った。供試品種は Latisail, Ambemohar 159, Pankhari 203, Ambemohar 102, Ka$\bmod 253$, Kataribhog 抽びレイホウである。

結果は第 1 表に示した。レイホウのみ発病が認められ たが，供陚した判別品種は病徽観察および㞍し接種とも に陰性であった。

実験 II タイワンツマグロヨコバイを用いた試験

1977年，接種および戻し接種にタイワンッマグロヨコ バイを用いて，実験 I とほぼ同様に行った。接種は，株 当り雄成虫 3 頭または 4,5 令㭃虫 6 頭で行った。供試 品種は, 実験 I に用いた品種に台中在来 1 号, FK 135, およびIR 8 を追加した。 